\title{
Factors involved in the pathogenesis of Helicobacter pylori infection
}

\author{
D. Olivares and J. P. Gisbert \\ Service of Digestive Diseases. Hospital Universitario de La Princesa. Madrid, Spain
}

Olivares D, Gisbert JP. Factors involved in the pathogenesis of Helicobacter pylori infection. Rev Esp Enferm Dig 2006; 98 : 374-386.

\begin{abstract}
ABBREVIATIONS
vacA: vacuolizing cytotoxin A; VEGF: vascular endothelial growth factor; $\operatorname{cagA}$ : cytotoxin-associated gene A; MAP: mitogen-activated protein kinases; IL: interleukin; LPS: lipopolysaccharide; MHC II: major histocompatibility complex II; COX: cyclooxygenase; ROS: reactive oxygen species; SOD: superoxide dismutase; iNOS: inducible nitric oxide synthase; NO: nitric oxide.
\end{abstract}

\section{INTRODUCTION}

Helicobacter pylori is a bacterium that chronically colonizes the gastric epithelium and infects approximately half of the human population worldwide. This pathogen is responsible for chronic gastritis and a high percentage of peptic ulcers, and its presence has been correlated to gastric cancer development (1-4).

Several factors have been associated with this germ's aggressiveness and hence implicated in epithelial damage, including vacuolizing cytotoxin (VacA), cytotoxinassociated gene A ( $\operatorname{cagA}$ ), surface lipopolysaccharide (LPS), bacterial urease, flagella, surface adhesins, oxidiz-

Recibido: 01-03-05.

Aceptado: 22-06-05.

Correspondencia: Javier P. Gisbert. Playa de Mojácar, 29. Urb. Bonanza. 28669 Boadilla del Monte. Madrid. Fax: 914022 299. e-mail: gisbert@meditex.es ing radicals, and citokines produced by leukocytes in response to infection.

On the other hand, there is increasing evidence that $H$. pylori species are genetically diverse, that such diversity is associated with different aggresiveness degrees on the mucosa, and hence with gastric mucosal inflammation to different extents and a variety of clinical prognoses for infected patients (5). H. pylori genoma includes more than 1,000 preserved genes and strain-specific genes. This bacterium may acquire or lose exogenous DNA, and thus follows an ongoing microevolution model allowing high genetic variability, which may result in strains adapted to multiple adverse environments. Such variability also results from a high recombination rate during colonization of one host by non-related $H$. pylori species, in addition to a high frequency of mutation (6-11).

The objective of this paper is to review the characteristics, and both the in vivo and in vitro effects, of major bacterial factors related to $H$. pylori virulence on human epithelial cells, as well as the effects deriving from $H$. $p y$ lori's intrinsic genetic variability.

\footnotetext{
ADHESINS

The process of $H$. pylori infection acquisition may be divided in two stages: a) adhesion to the epithelial cell layer; and b) induction of proinflammatory cytokines (12-14). Adhesion is mediated by $H$. pylori adhesins; these include BabA, which binds the host's Lewis ${ }^{\mathrm{b}}$ epitope, a molecule that has been suggested to play a crucial role in the development of gastric adenocarcinoma, peptic ulcer, and chronic gastritis (15-21). The polymorphic $b a b A$ gene has two alleles ( $b a b A 1$ and $b a b A 2)$, with the latter coding for protein BabA. They only differ in a number of 10-base-pair repeats containing a transcription start codon (19). The presence of babA2 has been seen to correlate to that of other pathogenic genes (cagA and the $\mathrm{s} 1$ and $\mathrm{m} 1$ alleles of $v a c A$ ) (22).
} 
Another protein involved in adhesion is NAP (neutrophil-activating protein), coded for by the napA gene and isolated from the plasma membrane protein fraction of $H$. pylori. Besides its function as a bacterial ferritin for iron capture, it plays different roles when secreted or presented on the bacterial surface, including affinity for ceramides present in cell plasma membranes. The NAP protein also has a high affinity for sulphated ceramides, the $\mathrm{SO}_{3}$-Lewis ${ }^{a}$ blood antigen group, and to a lesser extent the Lewis ${ }^{x}$ and $\mathrm{SO}_{3}$-Lewis ${ }^{x}$ groups, which demonstrates NAP function as an adhesin (23).

H. pylori also has a hemagglutinin coded for by the hpaA gene, which binds $\mathrm{N}$-acetylneuraminyl $\alpha(2,3)$-lactose and sialic acid remnants, since the reversibility of $H$. pylori-to-gastric cell binding has been demonstrated using sialyllactose or the glycoprotein fetuin (24-26).

In summary, it may be concluded that the presence of adhesins allows the involved strain a greater infective capability on the mucosa.

\section{VACUOLIZING CYTOTOXIN (VacA)}

All H. pylori strains have a vacA gene coding for a 87 $\mathrm{kDa}$ cytotoxin that induces epithelial cell vacuolization (27-32), but only 50 to $65 \%$ of $\mathrm{H}$. pylori strains do produce the cytotoxic protein. Infection by toxin-producing H. pylori strains has been seen to be more frequent in patients with peptic ulcer (30,33-35) and gastric cancer (3538 ) when compared to patients with only gastritis.

Two polymorphic regions have been documented within vacA (39). One is on the second half of the signal sequence $(\mathrm{s} 1 \mathrm{a} / \mathrm{s} 1 \mathrm{~b} / \mathrm{s} 1 \mathrm{c}$ or $\mathrm{s} 2)$, the other on the central region ( $\mathrm{m} 1$ or $\mathrm{m} 2)$. Sequence $\mathrm{s} 1$, but not sequence $\mathrm{s} 2$, is closely linked to the cytotoxin's in vitro activity, peptic ulcer, and the presence of gene $\operatorname{cag} A(33,39)$. In contrast, cagA is not associated to cytotoxicity in epithelial cells, as has been seen in a study following $\operatorname{cag} A$ gene mutation (40). Therefore, the presence of $\operatorname{cagA}$ is not essential for cytotoxicity induction.

In contrast to s1 strains, s2 strains only express the VacA protein in small amounts, and only exhibit mild cell vacuolization (38). In this regard, it has been postulated that the clinical progression of $H$. pylori infection is dependent upon the vacA genotype. This hypothesis was demonstratedin a study with patient-derived strains, which were $\mathrm{s} 1-\mathrm{m} 1$ or $\mathrm{s} 1-\mathrm{m} 2$ in most cases, and the s1 strain was shown to be present in all patients with peptic ulcer analyzed, and in most individuals diagnosed with gastritis, whereas all s2 strains derived from patients with gastritis exclusively. On the other hand the s2-m1 combination was found in no patient in this study (38). It may be concluded that the s1 allele is linked to peptic ulcer development, and hence to greater virulence. However, despite this association between $\mathrm{s} 1 / \mathrm{m} 1$ vacA genotype and presence of peptic ulcer, together with an increased infiltration by neutrophils and lymphocytes in vivo, greater in ulcer patients versus gastritis patients, this association is not so obvious in Asian countries, where both conditions exhibit a similar incidence regarding the $\mathrm{s} 1 / \mathrm{m} 1$ genotype $(41,42)$.

The mechanism through which VacA induces vacuolization is only partially understood. This protein is thought to be hexameric, and its assembly is favored by an acidic $\mathrm{pH}$, resulting in an anion-selective channel across the cell's lipid bilayer (43-46). It is then translocated to the cytosol, where it interferes with the vesicular transit of lysosomes, and may again set up an ion channel across endosomal membranes, which is partly responsible for the vacuolization process $(47,48)$.

The process by which VacA induces apoptosis (genetically "programmed" cell death) is not so clear. Fas/CD95 receptor activation (49) has been suggested, which would lead to apoptosis through the activation of caspases 3 and 8. A study has observed that the microinjection of cytotoxin-coding DNA results in cytochrome c release and apoptosis. VacA has been recently seen to interact with mitochondria, thus enhancing apoptosis (50). However, factors other than VacA must be involved in apoptosis, since VacA immunodepletion in vitro does not result in a complete abolition of apoptosis (43).

On the other hand, the vascular endothelial growth factor (VEGF), a well-characterized angiogenic factor, may induce mucosal recovery by stimulating vascularization and nutrient supply (51). VEGF overexpression has been seen in human gastric carcinomas (52-54), as has overexpression of factors similar to the endothelial growth factor and cyclooxygenase-2 (COX-2), a prostaglandin-producing enzyme, both in vitro $(55,56)$ and in vivo (57-59); the latter may in turn stimulate VEGF production (29). A study has shown that $H$. pylori strains expressing the VacA protein (also called $\mathrm{Tox}^{+}$) overexpress VEGF production through MAP kinase activation, whereas Tox $^{-}$strains do not (51). Therefore, the presence of VacA may induce the expression of VEGF and lead to the development of tumorigenic processes.

\section{THE $\operatorname{cag} A$ GENE}

The cytotoxin-associated gene A ( $\operatorname{cag} A)$ codes for a highly immunoreactive, high-molecular-weight (120-140 $\mathrm{kDa}$ ) protein present in approximately $60 \%$ of $\mathrm{H}$. pylori strains (28). In vitro studies have shown that $H$. pylori capability to induce chemokines in gastric epithelial cell lines is variable, and thisonly occurs when a CagA phenotype is present (60-62). In vivo, infection by CagA+ strains induces a greater immune response and more severe gastritis (63-65). Several studies have shown that infection by $\mathrm{cagA} \mathrm{A}^{+}$strains is associated with a higher frequency of peptic ulcer $(65,66)$, gastric atrophy $(63-65)$ and gastric cancer (67-69) except in Asian subjects. As is the case with vacA, no association exists between $\operatorname{cagA}$ genotype and clinical status in Asian subjects: both 
asymptomatic individuals and patients diagnosed with duodenal ulcer or gastric cancer express CagA and VacA with the same frequency $(70,71)$.

The $\operatorname{cag} A$ gene is a part of a pathogenicity island (cagPAI) around $40 \mathrm{kDa}$ in size, which includes 31 genes whose products play a role in chemokine stimulation and MAP kinase (a class of substrate-phosphorilating proteins involved in multiple cell signaling pathways) activation, with the subsequent induction of proinflammatory factors. The capability for interleukin-8 (IL-8) production by epithelial cells has been shown to remain unaffected when cagA-deleted mutant cells (i. e., strains lacking this gene) are used. In contrast, the deletion of other cag-PAI genes does eventually suppress it $(20,21,72,73)$.

Since $H$. pylori may easily lose or acquire exogen DNA, cag-PAI may have been acquired from other organism by horizontal transfer, as its $\mathrm{G}+\mathrm{C}$ contents differs from that in the remaining genoma (74-77). Several studies have revealed that cag-PAI may present as a single uninterrupted unit, separated in two regions by the insertional sequence IS605 or a chromosome fragment, or partially deleted $(28,76,78,79)$.

The capability of $H$. pylori strains for IL- 8 induction correlates with the presence of cag-PAI. While cag-PAI prevails in patients with dyspepsia or duodenal ulcer, no significant differences exist between both conditions regarding its presence $(78,80)$.

Some cag-PAI products show homology to the type-IV translocation system in Agrobacterium tumefaciens and Bordetella pertussis, which operate to transfer bacterial factors into the host cell $(76,81,82)$. Using this system, $H$. pylori may directly "inject" a number of factors into epithelial cells, including protein $\mathrm{CagA}$, which has been seen to be phosphorilated (83) and may bind the cell's SHP-2 phosphatase (37), involved in cell growth and motility; its disregulation may therefore result in cell proliferation changes and gastric cancer development.

Structural analyses have shown that CagA varies in size among the various $H$. pylori strains (84-87). Such variation derives from the presence of a number of repeats in an amino acid sequence at the carboxylic end, which may influence the pathogenicity of $\operatorname{cag} A^{+}$strains as a result of varied phosphorilation sites, and hence protein activity in terms of the effective binding of SHP-2 (51).

Another gene within cag-PAI is $\operatorname{cagE}$, which is a part of the type-IV secretion system (81). It is required for IL-8 inducion, and shows homology with genes $p t l F$ and virB4 of $B$. pertussis and A. tumefaciens, respectively (82). Finally, a positive correlation between the presence of $\mathrm{H}$. pylori $\mathrm{cagE}^{+}$strains and duodenal ulcer has been found.

\section{LIPOPOLYSACCHARIDE}

H. pylori's lipopolysaccharide (LPS) has been involved in the bacteria-host interaction. LPS is made up of three parts: hydrophobic lipid A, hydrophilic O-antigenic polysaccharide region, and polysaccharide core, which connects the former two (88). Lipid A is the component responsible for LPS immune and endotoxic properties. $H$. pylori LPS has a low toxicity when compared for instance to that Salmonella's or Escherichia coli's (89). This low biological activity may contribute to prolonged infection and chronic mucosal inflammation (90).

LPS antigenic structure is similar to that of antigens in the host's Lewis ${ }^{\mathrm{x}}$ and Lewis ${ }^{y}$ blood groups (91), which may explain the presence of $H$. pylori-induced auto-antibodies, which in turn may contribute to the development of atrophic gastritis. In addition, the $\mathrm{H}^{+} / \mathrm{K}^{+}$pump has been seen to have Lewis ${ }^{y}$ epitopes, and may be a target for the immune system in chronic gastritis (92). H. pylori antigens similar to Lewis' have also been seen to be more commonly expressed in $\mathrm{cagA}^{+}$strains versus cagA strains, which would stimulate a stronger autoimmune response in bacteria carrying the $\operatorname{cag} A$ gene (93).

On the other hand, selected regions have been identified within $H$. pylori genoma with a high number of repeats for a one or two nucleotides; some of these repeats lie within ORF (Open Reading Frame) sequences that potentially correspond to genes (77). Nucleotide unpairing upon the displacement of a DNA strand on the other strand is a phenomenon that results in a "gained" or "lost" unit in the reading schedule during transcription, which may in turn result in a missed start codon or mutated proteins, this being a factor increasing $H$. pylori genetic variability -this process has been designated slippedstrand mispairing (94)-. Similar repeat sequences have been found in other organisms such as Haemophilus influenzae $(95,96)$. In the "phase variable gene" class belong a number of genes coding for enzymes involved in LPS biosynthesis, membrane proteins, or other proteins (e.g., $\operatorname{cagA}$ ); these genes may produce variants unlike the genic product in one same bacterial population.

\section{FLAGELLA AND MOBILITY}

H. pylori mobility is facilitated by flagella, complex extracellular structures that require energy for operation. H. pylori has 5 to 7 flagella on one of its poles. Human immunoglobulins are usually directed against $H$. pylori flagellar proteins (97). A peculiar characteristic of these bacterial flagella is that they are covered in a lipoprotein sheath protecting them against gastric acid (98).

H. pylori strains with mutated flagella are less virulent than wild-type strains, which suggests that flagella are crucial for the pathogenetic process. Every flagellum is made up of two flagellins, FlaA and FlaB (99), an unusual characteristic not shared by the rest of flagellar proteins, which are homopolymeric in nature. FlaB is located at the flagellum's base, whereas FlaA -which is more abundant- is on the outside. Removal of both flagellins $\left(\mathrm{FlaA}^{-} / \mathrm{FlaB}^{-}\right)$results in nonmobile bacteria (100) that 
nonetheless keep a wild-type-like adherence capacity (14), and that can only efficiently infect in early infection stages.

\section{UREASE}

H. pylori contains urease, which is the enzyme more abundantly produced by thse bacteria. It is a significant survival factor for $\mathrm{H}$. pylori, since ammonium $\left(\mathrm{NH}_{4}^{+}\right)$is produced from urea in the stomach. $\mathrm{NH}_{4}{ }^{+}$neutralizes $\mathrm{HCl}$ and allows $H$. pylori to colonize the gastrointestinal tract. $\mathrm{NH}_{4}{ }^{+}$concentration in the stomach of infected patients is significantly higher than in non-infected subjects (101). Similarly, $\mathrm{NH}_{4}^{+}$levels are higher in infected patients than in these same patients following $H$. pylori eradication (102). $\mathrm{NH}_{4}^{+}$has a number of toxic effects within the bowel, including DNA synthesis disorders, increased risk for viral infection, and carcinogenesis (103). Furthermore, a decrease in oxygen use by gastric cells has been reported in cultures (104). In vitro, the high levels of $\mathrm{NH}_{4}^{+}$generated by $H$. pylori have a significant effect on reduced cell viability, an effect unseen in the absence of urea and in strains with non-functional urease. These effects have been seen to be reversible when urease is added in the medium, and the number of viable cells diminishes anew (103).

Urease is essential for colonization, as has been demonstrated in experiments using $H$. pylori strains with non-functional urease (105). These strains are unable to colonize under hypochlorhydria conditions (106), which demonstrates that urease is essential for survival regardless of its role in gastric acid neutralization.

On the other hand, major histocompatibility complex II (MHC II) molecules regulate immune response through antigen presentation to CD4 T cells. The binding of $H$. pylori to MHC II through urease has been examined, with a resulting increase in gastric cell apoptosis (107). Apoptosis induction is dependent upon MHC II expression, and may become eventually blocked when anti-MHC II antibodies are used; cells deficient in MHC II expression also show no $H$. pylori-induced apoptosis (107).

\section{H. PYLORI-INDUCED FREE RADICALS}

Oxygen radicals (superoxide and hydrogen peroxide ions) derived from neutrophils activated by $H$. pylori infection damage the gastric mucosa (108-113). A positive association between reactive oxygen species (ROS) production and $H$. pylori-related infection and histologic changes (108). Cell protection against ROS is induced by the activation of ROS-sequestering enzymes, including superoxide dismutase (SOD), catalase, and glutathione peroxidase.
Some authors, using an epithelial cell line, found that exposure to ROS in the absence of $H$. pylori reduced cell survival to $84 \%$ (114). On the other hand, exposure of these cells to ROS following incubation with $H$. pylori reduced survival to 73 and $39 \%$ for $\mathrm{cagA}^{+}$and $\mathrm{cagA}^{-}$ strains, respectively. SOD activity has also been estimated, and was found to be higher in cells incubated with $\operatorname{cag}^{+}$strains versus cag $A^{-}$strains. Similarly, higher catalase and glutathione peroxidase levels have been described in $\mathrm{cag} A^{+}$strains (114). This increased activity of enzymes suppressing agents that may potentially damage DNA following exposure to $\operatorname{cag} A^{+}$strains is likely a source of higher viability for cells after exposure to ROS (73\%), when compared to cells exposed to $\mathrm{cag}^{-}$strains (39\%) (114).

On the other hand, chloramine $\left(\mathrm{NH}_{3} \mathrm{Cl}\right)$ is a toxic oxidizing agent produced in the gastric mucosa as a consequence of $H$. pylori invasion. In neutrophils, the enzyme myeloperoxidase catalizes chloride oxidation by $\mathrm{H}_{2} \mathrm{O}_{2}$ (mainly resulting from the aerobic metabolism of neutrophils activated by the presence of pathogenic organisms) to hypochlorous acid. This reacts with $\mathrm{NH}_{4}{ }^{+}$as derived from $H$. pylori metabolism, and produces chloramine (115), a very toxic substance because of its lipophilicity and low molecular weight, which may easily cross the cell's plasma membrane.

\section{INDUCTION OF ENZYMES AND CYTOKINES BY H. PYLORI}

COX enzymes catalize the conversion of arachidonic acid to prostanoids such as prostaglandin $\mathrm{E}_{2}$, which protect the gastric mucosa from apoptosis by increasing cell proliferation $(116,117)$. Two isoenzymes exist: COX-1 and COX-2; the former is constituent and the latter inducible in case of injury, and mediates inflammation among other processes (116-119). H. pylori-related gastritis has been shown to induce COX-2 expression according to type of bacterial strain $(58,59,120-127)$, which may in part account for differential pathogenicity $(127,128)$. Infection by $H$. pylori cag $A^{+}$strains has been seen to overexpress COX-2 in patients with gastric cancer (127). In addition, some studies have demonstrated that organism eradication is associated with a decreased gastric COX-2 expression $(59,125,129)$.

Another molecule, nitric oxyde (NO), has been documented to contribute to gastric mucosal protection by increasing blood flow and inhibiting leukocyte adhesion to the endothelium (130). There is no inducible NO synthase (iNOS) in the normal gastric mucosa, but its expression increases in patients with $H$. pylori-related gastritis (59). Both iNOS and COX-2 are induced by cytokines, including IL-1 $\beta$, tumor necrosis factor $\alpha$, interferon $\gamma$, phorbol esters, and growth factors, as well as bacterial lipopolysaccharides (131-133). 
Epithelial gastric cells substantially contribute to the cytokine-induced proinflammatory response to $H$. pylori infection, both through active production and the capture of cytokines derived from the lamina propria and intraepithelial leukocytes. Epithelial IL-1 $\beta$, IL-6, IL-8, and tumor necrosis factor $\alpha$ levels have been shown to be significantly higher in infected patients versus healthy subjects (134). There is also interferon $\gamma$, but not IL-4, overexpression in infected patients, which suggests a Th1 lymphocyte-mediated response (134-137).

Finally, increased interferon $\gamma$ levels may contribute to gastric inflammation no only through phagocyte and neutrophil activation, but also the induction of MHC II overexpression in epithelial cells, with an ensuing increase in H. pylori adhesion (138).

\section{CONCLUSIONS}

H. pylori is a highly efficient pathogenic organism in terms of colonization, with the potential to cause a number of conditions ranging from chronic gastritis to gastric cancer. A major part of its colonizing efficiency results from genetic dynamism given the small size of the organism's genoma, which confers a higher feasibility for recombination proceses, and hence may give rise to a high amount of recombinant gene products with a high potential for adaptation. In addition, mutation frequency is high given the lack of a number of DNA-repairing enzymes, which together with the presence of "phase variable genes" allows genetic variability, thus facilitating bacterial host adaptation. $H$. pylori's adaptive process is mainly mediated by LPS, which allows it to evade the immune system. Other virulence factors such as cagA, $v a c A$, or $b a b A$ are also subject to genetic variability, which extends the range of potentially virulent strains, and difficults both strain characterization and the establishment of an accurate clinical prognosis in patients infected by one of these strains. Nevertheless, a more detailed understanding of $H$. pylori-related pathogenic factors will likely be of help in establishing which strains are more virulent, and will allow a selection of patients who most likely will benefit from eradicating therapy.

\section{ACKNOWLEDGMENTS}

This review has been partly funded by a grant from Instituto de Salud Carlos III (03/02).

\section{REFERENCES}

1. Warren JR, Marshall BJ. Unidentified curved bacilli on gastric epithelium in active chronic gastritis. Lancet 1983; 1: 1273-5.
2. NIH Consensus Conference. Helicobacter pylori in peptic ulcer disease. NIH consensus development panel. JAMA 1994; 272: 65-9.

3. Marshall BJ, Goodwin CS, Warren JR, Murray R, Blincow ED, Blackbourn SJ, et al. Prospective double-blind trial of duodenal ulcer relapse after eradication of Campylobacter pylori. Lancet 1988; 2: 1437-42.

4. Parsonnet J, Friedman GD, Vandersteen DP, Chang Y, Vogelman $\mathrm{JH}$, Orentreich N, et al. Helicobacter pylori infection and the risk of gastric carcinoma. N Engl J Med 1991; 325: 1127-31.

5. Shimoyama T, Crabtree JE. Bacterial factors and immune pathogenesis in Helicobacter pylori infection. Gut 1998; 43 (Supl. 1): S2-5.

6. Salama N, Guillemin K, McDaniel TK, Sherlock G, Tompkins L, Falkow S. A whole-genome microarray reveals genetic diversity among Helicobacter pylori strains. Proc Natl Acad Sci USA 2000; 97: 14668-73.

7. Blaser MJ, Kirschner D. Dynamics of Helicobacter pylori colonization in relation to the host response. Proc Natl Acad Sci USA 1999; 96: 8359-64.

8. Falush D, Kraft C, Taylor NS, Correa P, Fox JG, Achtman M, et al. Recombination and mutation during long-term gastric colonization by Helicobacter pylori: estimates of clock rates, recombination size, and minimal age. Proc Natl Acad Sci USA 2001; 98: 15056-61.

9. Israel DA, Salama N, Krishna U, Rieger UM, Atherton JC, Falkow $\mathrm{S}$, et al. Helicobacter pylori genetic diversity within the gastric niche of a single human host. Proc Natl Acad Sci USA 2001; 98 : 14625-30.

10. Webb GF, Blaser MJ. Dynamics of bacterial phenotype selection in a colonized host. Proc Natl Acad Sci USA 2002; 99: 3135-40.

11. Kuipers EJ, Israel DA, Kusters JG, Gerrits MM, Weel J, van Der Ende A, et al. Quasispecies development of Helicobacter pylori observed in paired isolates obtained years apart from the same host. J Infect Dis 2000; 181: 273-82.

12. Crabtree JE. Role of cytokines in pathogenesis of Helicobacter pylori-induced mucosal damage. Dig Dis Sci 1998; 43: 46S-55S.

13. Montecucco C, Rappuoli R. Living dangerously: how Helicobacter pylori survives in the human stomach. Nat Rev Mol Cell Biol 2001; 2: 457-66.

14. Evans DJ, Jr., Evans DG. Helicobacter pylori adhesins: review and perspectives. Helicobacter 2000; 5: 183-95.

15. Gerhard M, Lehn N, Neumayer N, Boren T, Rad R, Schepp W, et al. Clinical relevance of the Helicobacter pylori gene for blood-group antigen-binding adhesin. Proc Natl Acad Sci USA1999; 96: 1277883.

16. Guruge JL, Falk PG, Lorenz RG, Dans M, Wirth HP, Blaser MJ, et al. Epithelial attachment alters the outcome of Helicobacter pylori infection. Proc Natl Acad Sci USA 1998; 95: 3925-30.

17. Ilver D, Arnqvist A, Ogren J, Frick IM, Kersulyte D, Incecik ET, et al. Helicobacter pylori adhesin binding fucosylated histo-blood group antigens revealed by retagging. Science 1998; 279: 373-7.

18. Mizushima T, Sugiyama T, Komatsu Y, Ishizuka J, Kato M, Asaka M. Clinical relevance of the babA2 genotype of Helicobacter pylori in Japanese clinical isolates. J Clin Microbiol 2001; 39: 2463-5.

19. Pride DT, Meinersmann RJ, Blaser MJ. Allelic Variation within Helicobacter pylori babA and babB. Infect Immun 2001; 69: 1160-71.

20. Prinz C, Schoniger M, Rad R, Becker I, Keiditsch E, Wagenpfeil S, et al. Key importance of the Helicobacter pylori adherence factor blood group antigen binding adhesin during chronic gastric inflammation. Cancer Res 2001; 61: 1903-9.

21. Rad R, Gerhard M, Lang R, Schoniger M, Rosch T, Schepp W, et al. The Helicobacter pylori blood group antigen-binding adhesin facilitates bacterial colonization and augments a nonspecific immune response. J Immunol 2002; 168: 3033-41.

22. Zambon CF, Navaglia F, Basso D, Rugge M, Plebani M. Helicobacter pylori babA2, cagA, and s1 vacA genes work synergistically in causing intestinal metaplasia. J Clin Pathol 2003; 56: 287-91.

23. Namavar F, Sparrius M, Veerman EC, Appelmelk BJ, Vandenbroucke-Grauls CM. Neutrophil-activating protein mediates adhesion of Helicobacter pylori to sulfated carbohydrates on high-molecular-weight salivary mucin. Infect Immun 1998; 66: 444-7.

24. Evans DG, Evans DJ, Jr., Moulds JJ, Graham DY. N-acetylneuraminyllactose-binding fibrillar hemagglutinin of Campylobacter pylori: a putative colonization factor antigen. Infect Immun 1988; 56: 2896-906. 
25. Kimmel B, Bosserhoff A, Frank R, Gross R, Goebel W, Beier D. Identification of immunodominant antigens from Helicobacter pylori and evaluation of their reactivities with sera from patients with different gastroduodenal pathologies. Infect Immun 2000; 68: 915-20.

26. Simon PM, Goode PL, Mobasseri A, Zopf D. Inhibition of Helicobacter pylori binding to gastrointestinal epithelial cells by sialic acid-containing oligosaccharides. Infect Immun 1997; 65: 750-7.

27. Leunk RD, Johnson PT, David BC, Kraft WG, Morgan DR. Cytotoxic activity in broth-culture filtrates of Campylobacter pylori. J Med Microbiol 1988; 26: 93-9.

28. Covacci A, Censini S, Bugnoli M, Petracca R, Burroni D, Macchia $\mathrm{G}$, et al. Molecular characterization of the 128-kDa immunodominant antigen of Helicobacter pylori associated with cytotoxicity and duodenal ulcer. Proc Natl Acad Sci USA1993; 90: 5791-5.

29. Cover TL, Tummuru MK, Cao P, Thompson SA, Blaser MJ. Divergence of genetic sequences for the vacuolating cytotoxin among $\mathrm{He}$ licobacter pylori strains. J Biol Chem 1994; 269: 10566-73.

30. Figura N, Guglielmetti P, Rossolini A, Barberi A, Cusi G, Musmanno RA, et al. Cytotoxin production by Campylobacter pylori strains isolated from patients with peptic ulcers and from patients with chronic gastritis only. J Clin Microbiol 1989; 27: 225-6.

31. Harris PR, Cover TL, Crowe DR, Orenstein JM, Graham MF, Blaser $\mathrm{MJ}$, et al. Helicobacter pylori cytotoxin induces vacuolation of primary human mucosal epithelial cells. Infect Immun 1996; 64: 4867 71.

32. Schmitt W, Haas R. Genetic analysis of the Helicobacter pylori vacuolating cytotoxin: structural similarities with the IgA protease type of exported protein. Mol Microbiol 1994; 12: 307-19.

33. Atherton JC, Peek RM, Jr., Tham KT, Cover TL, Blaser MJ. Clinical and pathological importance of heterogeneity in vacA, the vacuolating cytotoxin gene of Helicobacter pylori. Gastroenterology 1997; 112: 92-9.

34. Boquet P, Ricci V, Galmiche A, Gauthier NC. Gastric cell apoptosis and $\mathrm{H}$. pylori: has the main function of VacA finally been identified? Trends Microbiol 2003; 11: 410-3.

35. Hou P, Tu ZX, Xu GM, Gong YF, Ji XH, Li ZS. Helicobacter pylori vacA genotypes and cagA status and their relationship to associated diseases. World J Gastroenterol 2000; 6: 605-7.

36. Telford JL, Covacci A, Ghiara P, Montecucco C, Rappuoli R. Unravelling the pathogenic role of Helicobacter pylori in peptic ulcer: potential new therapies and vaccines. Trends Biotechnol 1994; 12: 4206.

37. Ricci V, Ciacci C, Zarrilli R, Sommi P, Tummuru MK, Del Vecchio Blanco C, et al. Effect of Helicobacter pylori on gastric epithelial cell migration and proliferation in vitro: role of $\mathrm{VacA}$ and $\mathrm{CagA}$. Infect Immun 1996; 64: 2829-33.

38. Rudi J, Kolb C, Maiwald M. Diversity of Helicobacter pylori vacA and cagA Genes and Relationship to VacA and CagA Protein Expression, Cytotoxin Production and Associated Diseases. J Clin Microbiol 1998; 36: 944-8.

39. Atherton JC, Cao P, Peek RM, Jr., Tummuru MK, Blaser MJ, Cover TL. Mosaicism in vacuolating cytotoxin alleles of Helicobacter pylori. Association of specific vacA types with cytotoxin production and peptic ulceration. J Biol Chem 1995; 270: 17771-7.

40. Tummuru MK, Cover TL, Blaser MJ. Mutation of the cytotoxin-associated cagA gene does not affect the vacuolating cytotoxin activity of Helicobacter pylori. Infect Immun 1994; 62: 2609-13.

41. Shimoyama T, Yoshimura T, Mikami T, Fukuda S, Crabtree JE, Munakata A. Evaluation of Helicobacter pylori vacA genotype in Japanese patients with gastric cancer. J Clin Pathol 1998; 51: 299-301.

42. Ito Y, Azuma T, Ito S, Miyaji H, Hirai M, Yamazaki Y, et al. Analysis and typing of the vacA gene from cagA-positive strains of Helicobacter pylori isolated in Japan. J Clin Microbiol 1997; 35: 1710-4.

43. Cover TL, Hanson PI, Heuser JE. Acid-induced dissociation of VacA, the Helicobacter pylori vacuolating cytotoxin, reveals its pattern of assembly. J Cell Biol 1997; 138: 759-69.

44. de Bernard M, Papini E, de Filippis V, Gottardi E, Telford J, Manetti $\mathrm{R}$, et al. Low $\mathrm{pH}$ activates the vacuolating toxin of Helicobacter pylori, which becomes acid and pepsin resistant. J Biol Chem 1995; 270: 23937-40.

45. Iwamoto H, Czajkowsky DM, Cover TL, Szabo G, Shao Z. VacA from Helicobacter pylori: a hexameric chloride channel. FEBS Lett 1999; 450: 101-4.
46. Lupetti P, Heuser JE, Manetti R, Massari P, Lanzavecchia S, Bellon PL, et al. Oligomeric and subunit structure of the Helicobacter pylori vacuolating cytotoxin. J Cell Biol 1996; 133: 801-7.

47. Montecucco C. Protein toxins and membrane transport. Curr Opin Cell Biol 1998; 10: 530-6.

48. Montecucco C, Papini E, de Bernard M, Zoratti M. Molecular and cellular activities of Helicobacter pylori pathogenic factors. FEBS Lett 1999; 452: 16-21.

49. Rudi J, Kuck D, Strand S, von Herbay A, Mariani SM, Krammer PH, et al. Involvement of the CD95 (APO-1/Fas) receptor and ligand system in Helicobacter pylori-induced gastric epithelial apoptosis. J Clin Invest 1998; 102: 1506-14.

50. Galmiche A, Rassow J, Doye A, Cagnol S, Chambard JC, Contamin $\mathrm{S}$, et al. The N-terminal $34 \mathrm{kDa}$ fragment of Helicobacter pylori vacuolating cytotoxin targets mitochondria and induces cytochrome $\mathrm{c}$ release. Embo J 2000; 19: 6361-70.

51. Caputo R, Tuccillo C, Manzo BA, Zarrilli R, Tortora G, Blanco Cdel $\mathrm{V}$, et al. Helicobacter pylori VacA toxin up-regulates vascular endothelial growth factor expression in MKN 28 gastric cells through an epidermal growth factor receptor-, cyclooxygenase-2-dependent mechanism. Clin Cancer Res 2003; 9: 2015-21.

52. Brown LF, Berse B, Jackman RW, Tognazzi K, Manseau EJ, Senger DR, et al. Expression of vascular permeability factor (vascular endothelial growth factor) and its receptors in adenocarcinomas of the gastrointestinal tract. Cancer Res 1993; 53: 4727-35.

53. Tian X, Song S, Wu J, Meng L, Dong Z, Shou C. Vascular endothelial growth factor: acting as an autocrine growth factor for human gastric adenocarcinoma cell MGC803. Biochem Biophys Res Commun 2001; 286: 505-12.

54. Yamamoto S, Yasui W, Kitadai Y, Yokozaki H, Haruma K, Kajiya$\mathrm{ma} \mathrm{G}$, et al. Expression of vascular endothelial growth factor in human gastric carcinomas. Pathol Int 1998; 48: 499-506.

55. Romano M, Ricci V, Di Popolo A, Sommi P, Del Vecchio Blanco C, Bruni CB, et al. Helicobacter pylori upregulates expression of epidermal growth factor-related peptides, but inhibits their proliferative effect in MKN 28 gastric mucosal cells. J Clin Invest 1998; 101: 160413.

56. Romano M, Ricci V, Memoli A, Tuccillo C, Di Popolo A, Sommi P, et al. Helicobacter pylori up-regulates cyclooxygenase- 2 mRNA expression and prostaglandin E2 synthesis in MKN 28 gastric mucosal cells in vitro. J Biol Chem 1998; 273: 28560-3.

57. Tuccillo C, Manzo BA, Nardone G, D’Argenio G, Rocco A, Di Popolo A, et al. Up-regulation of heparin binding epidermal growth factor-like growth factor and amphiregulin expression in Helicobacter pylori-infected human gastric mucosa. Dig Liver Dis 2002; 34: 498-505.

58. Zarrilli R, Tuccillo C, Santangelo M, Nardone G, Romano M. Increased COX-2, but not COX-1, mRNA expression in Helicobacter pylori gastritis. Am J Gastroenterol 1999; 94: 3376-8.

59. Fu S, Ramanujam KS, Wong A, Fantry GT, Drachenberg CB, James $\mathrm{SP}$, et al. Increased expression and cellular localization of inducible nitric oxide synthase and cyclooxygenase 2 in Helicobacter pylori gastritis. Gastroenterology 1999; 116: 1319-29.

60. Crabtree JE, Covacci A, Farmery SM, Xiang Z, Tompkins DS, Perry $\mathrm{S}$, et al. Helicobacter pylori induced interleukin-8 expression in gastric epithelial cells is associated with CagA positive phenotype. J Clin Pathol 1995; 48: 41-5.

61. Crabtree JE, Farmery SM, Lindley IJ, Figura N, Peichl P, Tompkins DS. CagA/cytotoxic strains of Helicobacter pylori and interleukin-8 in gastric epithelial cell lines. J Clin Pathol 1994; 47: 945-50.

62. Sharma SA, Tummuru MK, Miller GG, Blaser MJ. Interleukin-8 response of gastric epithelial cell lines to Helicobacter pylori stimulation in vitro. Infect Immun 1995; 63: 1681-7.

63. Yamaoka Y, Kita M, Kodama T, Sawai N, Imanishi J. Helicobacter pylori cagA gene and expression of cytokine messenger RNA in gastric mucosa. Gastroenterology 1996; 110: 1744-52.

64. Peek RM, Miller GG, Tham KT, Perez-Perez GI. Heightened inflammatory response and cytokine expression in vivo to cagA+ Helicobacter pylori strains. Lab Invest 1995; 73: 760-70.

65. Crabtree JE, Taylor JD, Wyatt JI, Heatley RV, Shallcross TM, Tompkins DS, et al. Mucosal IgA recognition of Helicobacter pylori $120 \mathrm{kDa}$ protein, peptic ulceration, and gastric pathology. Lancet 1991; 338: 332-5. 
66. Weel JF, van der Hulst RW, Gerrits Y, Roorda P, Feller M, Dankert $\mathrm{J}$, et al. The interrelationship between cytotoxin-associated gene A, vacuolating cytotoxin, and Helicobacter pylori-related diseases. J Infect Dis 1996; 173: 1171-5.

67. Parsonnet J, Friedman GD, Orentreich N, Vogelman H. Risk for gastric cancer in people with CagA positive or CagA negative Helicobacter pylori infection. Gut 1997; 40: 297-301.

68. Blaser MJ, Perez-Perez GI, Kleanthous H, Cover TL, Peek RM, Chyou $\mathrm{PH}$, et al. Infection with Helicobacter pylori strains possessing cagA is associated with an increased risk of developing adenocarcinoma of the stomach. Cancer Res 1995; 55: 2111-5.

69. Crabtree JE, Wyatt JI, Sobala GM, Miller G, Tompkins DS, Primrose JN, et al. Systemic and mucosal humoral responses to Helicobacter pylori in gastric cancer. Gut 1993; 34: 1339-43.

70. Park SM, Park J, Kim JG, Cho HD, Cho JH, Lee DH, et al. Infection with Helicobacter pylori expressing the cagA gene is not associated with an increased risk of developing peptic ulcer diseases in Korean patients. Scand J Gastroenterol 1998; 33: 923-7.

71. Yamaoka Y, Kodama T, Gutierrez O, Kim JG, Kashima K, Graham DY. Relationship between Helicobacter pylori iceA, cagA, and vacA status and clinical outcome: studies in four different countries. J Clin Microbiol 1999; 37: 2274-9.

72. Israel DA, Salama N, Arnold CN, Moss SF, Ando T, Wirth HP, et al. Helicobacter pylori strain-specific differences in genetic content, identified by microarray, influence host inflammatory responses. J Clin Invest 2001; 107: 611-20.

73. Yamaoka Y, Kwon DH, Graham DY. A M(r) 34,000 proinflammatory outer membrane protein (oipA) of Helicobacter pylori. Proc Natl Acad Sci USA2000; 97: 7533-8.

74. Akopyants NS, Clifton SW, Kersulyte D, Crabtree JE, Youree BE, Reece CA, et al. Analyses of the cag pathogenicity island of Helicobacter pylori. Mol Microbiol 1998; 28: 37-53.

75. Alm RA, Ling LS, Moir DT, King BL, Brown ED, Doig PC, et al. Genomic-sequence comparison of two unrelated isolates of the human gastric pathogen Helicobacter pylori. Nature 1999; 397: 17680 .

76. Censini S, Lange C, Xiang Z, Crabtree JE, Ghiara P, Borodovsky M, et al. cag, a pathogenicity island of Helicobacter pylori, encodes type I-specific and disease-associated virulence factors. Proc Natl Acad Sci USA1996; 93: 14648-53.

77. Tomb JF, White O, Kerlavage AR, Clayton RA, Sutton GG, Fleischmann RD, et al. The complete genome sequence of the gastric pathogen Helicobacter pylori. Nature 1997; 388: 539-47.

78. Jenks PJ, Megraud F, Labigne A. Clinical outcome after infection with Helicobacter pylori does not appear to be reliably predicted by the presence of any of the genes of the cag pathogenicity island. Gut 1998; 43: 752-8.

79. Maeda S, Yoshida H, Ikenoue T, Ogura K, Kanai F, Kato N, et al. Structure of cag pathogenicity island in Japanese Helicobacter pylori isolates. Gut 1999; 44: 336-41.

80. Audibert C, Burucoa C, Janvier B, Fauchere JL. Implication of the structure of the Helicobacter pylori cag pathogenicity island in induction of interleukin-8 secretion. Infect Immun 2001; 69: 1625-9.

81. Covacci A, Telford J, Del Giudice G, Parsonnet J, Rappuoli R. Helicobacter pylori virulence and genetic geography. Science 1999; 284 : 1328-33.

82. Tummuru MK, Sharma SA, Blaser MJ. Helicobacter pylori picB, a homologue of the Bordetella pertussis toxin secretion protein, is required for induction of IL-8 in gastric epithelial cells. Mol Microbiol 1995; 18: 867-76.

83. Asahi M, Azuma T, Ito S, Ito Y, Suto H, Nagai Y, et al. Helicobacter pylori CagA protein can be tyrosine phosphorylated in gastric epithelial cells. J Exp Med 2000; 191: 593-602.

84. Connolly DT, Heuvelman DM, Nelson R, Olander JV, Eppley BL, Delfino JJ, et al. Tumor vascular permeability factor stimulates endothelial cell growth and angiogenesis. J Clin Invest 1989; 84: 14708.

85. Romano M, Razandi M, Sekhon S, Krause WJ, Ivey KJ. Human cell line for study of damage to gastric epithelial cells in vitro. J Lab Clin Med 1988; 111: 430-40.

86. Ciardiello F, Caputo R, Bianco R, Damiano V, Fontanini G, Cuccato $\mathrm{S}$, et al. Inhibition of growth factor production and angiogenesis in human cancer cells by ZD1839 (Iressa), a selective epidermal growth factor receptor tyrosine kinase inhibitor. Clin Cancer Res 2001; 7: 1459-65.

87. Tortora G, Damiano V, Bianco C, Baldassarre G, Bianco AR, Lanfrancone L, et al. The RIalpha subunit of protein kinase A (PKA) binds to Grb2 and allows PKA interaction with the activated EGF-receptor. Oncogene 1997; 14: 923-8.

88. Marais A, Mendz GL, Hazell SL, Megraud F. Metabolism and genetics of Helicobacter pylori: the genome era. Microbiol Mol Biol Rev 1999; 63: 642-74.

89. Birkholz S, Knipp U, Nietzki C, Adamek RJ, Opferkuch W. Immunological activity of lipopolysaccharide of Helicobacter pylori on human peripheral mononuclear blood cells in comparison to lipopolysaccharides of other intestinal bacteria. FEMS Immunol Med Microbiol 1993; 6: 317-24.

90. Moran AP. The role of lipopolysaccharide in Helicobacter pylori pathogenesis. Aliment Pharmacol Ther 1996; 10 Supl 1: 39-50.

91. Aspinall GO, Monteiro MA, Pang H, Walsh EJ, Moran AP. Lipopolysaccharide of the Helicobacter pylori type strain NCTC 11637 (ATCC 43504): structure of the $\mathrm{O}$ antigen chain and core oligosaccharide regions. Biochemistry 1996; 35: 2489-97.

92. Appelmelk BJ, Simoons-Smit I, Negrini R, Moran AP, Aspinall GO, Forte JG, et al. Potential role of molecular mimicry between Helicobacter pylori lipopolysaccharide and host Lewis blood group antigens in autoimmunity. Infect and Immun 1996; 64: 2031-40.

93. Wirth HP, Yang M, Karita M, Blaser MJ. Expression of the human cell surface glycoconjugates Lewis $\mathrm{x}$ and Lewis y by Helicobacter pylori isolates is related to cagA status. Infect and Immun 1996; 64: 4598-605.

94. Levinson G, Gutman GA. Slipped-strand mispairing: a major mechanism for DNA sequence evolution. Mol Biol Evol 1987; 4: 203-21.

95. Moxon ER, Rainey PB, Nowak MA, Lenski RE. Adaptive evolution of highly mutable loci in pathogenic bacteria. Curr Biol 1994; 4: 2433.

96. Marshall DG, Dondon WG, Beesley SM. Helicobacter pylori -a conundrum of genetic diversity. Microbiology 1998; 144: 2925-39.

97. Ottemann KM, Lowenthal AC. Helicobacter pylori uses motility for initial colonization and to attain robust infection. Infect Immun 2002; 70: 1984-90.

98. Geis G, Suerbaum S, Forsthoff B, Leying H, Opferkuch W. Ultrastructure and biochemical studies of the flagellar sheath of Helicobacter pylori. J Med Microbiol 1993; 38: 371-7.

99. Kostrzynska M, Betts JD, Austin JW, Trust TJ. Identification, characterization, and spatial localization of two flagellin species in Helicobacter pylori flagella. J Bacteriol 1991; 173: 937-46.

100. Josenhans C, Labigne A, Suerbaum S. Comparative ultrastructural and functional studies of Helicobacter pylori and Helicobacter mustelae flagellin mutants: both flagellin subunits, FlaA and FlaB, are necessary for full motility in Helicobacter species. J Bacteriol 1995; 177: 3010-20.

101. Thomsen L, Tasman-Jones C, Morris A, Wiggins P, Lee S, Forlong C. Ammonia produced by Campylobacter pylori neutralizes $\mathrm{H}+$ moving through gastric mucus. Scand J Gastroenterol 1989; 24: 7618.

102. Chittajallu RS, Neithercut WD, Macdonald AM, McColl KE. Effect of increasing Helicobacter pylori ammonia production by urea infusion on plasma gastrin concentrations. Gut 1991; 32: 21-4.

103. Megraud F, Neman-Simha V, Brugmann D. Further evidence of the toxic effect of ammonia produced by Helicobacter pylori urease on human epithelial cells. Infect Immun 1992; 60: 1858-63.

104. Tsujii M, Kawano S, Tsuji S, Nagano K, Ito T, Hayashi N, et al. Ammonia: a possible promotor in Helicobacter pylori-related gastric carcinogenesis. Cancer Lett 1992; 65: 15-8.

105. Eaton KA, Brooks CL, Morgan DR, Krakowka S. Essential role of urease in pathogenesis of gastritis induced by Helicobacter pylori in gnotobiotic piglets. Infect Immun 1991; 59: 2470-5.

106. Eaton KA, Krakowka S. Effect of gastric $\mathrm{pH}$ on urease-dependent colonization of gnotobiotic piglets by Helicobacter pylori. Infect Immun 1994; 62: 3604-7.

107. Fan X, Gunasena H, Cheng Z. Helicobacter pylori Urease Binds to Class II MHC on Gastric Epithelial Cells and Induces Their Apoptosis. J Immunol 2000; 165: 1918-24.

108. Davies GR, Simmonds NJ, Stevens TR, Sheaff MT, Banatvala N, Laurenson IF, et al. Helicobacter pylori stimulates antral mucosal re- 
active oxygen metabolite production in vivo. Gut 1994; 35: 179-85.

109. Suzuki H, Miura S, Suzuki M, Terada S, Nakamura M, Tsuchiya M. Gastric mucosal injury: microcirculation and Helicobacter pylori. Keio J Med 1994; 43: 1-8.

110. Suzuki H, Miura S, Imaeda H, Suzuki M, Han JY, Mori M, et al. Enhanced levels of chemiluminescence and platelet activating factor in urease-positive gastric ulcers. Free Radic Biol Med 1996; 20: 44954.

111. Suzuki H, Suzuki M, Mori M, Kitahora T, Yokoyama H, Miura S, et al. Augmented levels of gastric mucosal leucocyte activation by infection with cagA gene-positive Helicobacter pylori. J Gastroenterol Hepatol 1998; 13: 294-300.

112. Suzuki H, Mori M, Suematsu M, Kai A. Helicobacter pylori-associated ammonia production enhances neutrophil-dependent gastric mucosal cell injury. Am J Physiol 1992; 263(5 Pt 1): G719-25.

113. Suzuki H, Yanaka A, Shibahara T, Matsui H, Nakahara A, Tanaka N, et al. Ammonia-induced apoptosis is accelerated at higher $\mathrm{pH}$ in gastric surface mucous cells. Am J Physiol Gastrointest Liver Physiol 2002; 283: G986-95.

114. Smoot DT, Elliott TB, Verspaget HW, Jones D, Allen CR, Vernon $\mathrm{KG}$, et al. Influence of Helicobacter pylori on reactive oxygen-induced gastric epithelial cell injury. Carcinogenesis 2000; 21: 2091-5.

115. Suzuki H, Seto K, Mori M, Suzuki M, Miura S, Ishii H. Monochloramine induced DNA fragmentation in gastric cell line MKN45. Am J Physiol 1998; 275: G712-6.

116. Gisbert JP, Pajares JM. Ciclooxigenasa-2 (COX-2), Helicobacter pylori y cáncer gástrico. Med Clin (Barc) 2003; 120: 189-93.

117. Gisbert JP, Pajares JM. Ciclooxigenasa-2 (COX-2) y lesiones gastroduodenales. ¿Alguna relación con Helicobacter pylori? Una revisión sistemática. Med Clin (Barc) 2003; 120: 550-8.

118. Lanas A, Martin-Mola E, Ponce J, Navarro F, Pique JM, Blanco FJ. Clinical strategy to prevent the gastrointestinal adverse effects of nonsteroidal anti-inflammatory agents. Gastroenterol Hepatol 2003; 26: 485-502.

119. Halter F, Tarnawski AS, Schmassmann A, Peskar BM. Cyclooxygenase 2-implications on maintenance of gastric mucosal integrity and ulcer healing: controversial issues and perspectives. Gut 2001; 49: 443-53.

120. Tatsuguchi A, Sakamoto C, Fukuda Y, Wada K, Akamatsu T, Tsukui $\mathrm{T}$, et al. Induction of cyclooxygenase- 2 in mesothelial cells in peritonitis caused by perforated ulcers - an immunohistochemical study in humans. Aliment Pharmacol Ther 2000; 14 Supl 1: 58-63.

121. Jackson LM, Wu KC, Mahida YR, Jenkins D, Hawkey CJ. Cyclooxygenase (COX) 1 and 2 in normal, inflamed, and ulcerated human gastric mucosa. Gut 2000; 47: 762-70.

122. Chan FK, To KF, Ng YP, Lee TL, Cheng AS, Leung WK, et al. Expression and cellular localization of COX-1 and -2 in Helicobacter pylori gastritis. Aliment Pharmacol Ther 2001; 15: 187-93.

123. Franco L, Talamini G, Carra G, Doria D. Expression of COX-1, COX-2, and inducible nitric oxide synthase protein in human gastric antrum with Helicobacter pylori infection. Prostaglandins Other Lipid Mediat 1999; 58: 9-17.
124. Kimura A, Tsuji S, Tsujii M, Sawaoka H, Iijima H, Kawai N, et al. Expression of cyclooxygenase-2 and nitrotyrosine in human gastric mucosa before and after Helicobacter pylori eradication. Prostaglandins Leukot Essent Fatty Acids 2000; 63: 315-22.

125. McCarthy CJ, Crofford LJ, Greenson J, Scheiman JM. Cyclooxygenase-2 expression in gastric antral mucosa before and after eradication of Helicobacter pylori infection. Am J Gastroenterol 1999; 94: 1218-23.

126. Byrne MF, Murphy JF, Corcoran PA, Atherton JC. Helicobacter pylori induces cyclooxygenase- 1 and cyclooxygenase-2 expression in vascular endothelial cells. Scand J Gastroenterol 2003; 38 : 1023-30.

127. Guo XL, Wang LE, Du SY, Fan CL, Li L, Wang P, et al. Association of cyclooxygenase-2 expression with $\mathrm{Hp}$-cagA infection in gastric cancer. World J Gastroenterol 2003; 9: 246-9.

128. Wilson KT, Ramanujam KS, Shirin H. Prostaglandin E inhibits Helycobacter pylori-induced apoptosis. Gastroenterology 1998; 116 : A530 (abstract).

129. Konturek PC, Rembiasz K, Konturek SJ, Stachura J, Bielanski W, Galuschka K, et al. Gene expression of ornithine decarboxylase, cyclooxygenase-2, and gastrin in atrophic gastric mucosa infected with Helicobacter pylori before and after eradication therapy. Dig Dis Sci 2003; 48: 36-46.

130. López-Belmonte J, Whittle BJ, Moncada S. The actions of nitric oxide donors in the prevention or induction of injury to the rat gastric mucosa. Br J Pharmacol 1993; 108: 73-8.

131. Xie QW, Cho HJ, Calaycay J, Mumford RA, Swiderek KM, Lee TD, et al. Cloning and characterization of inducible nitric oxide synthase from mouse macrophages. Science 1992; 256: 225-8.

132. Lowenstein CJ, Glatt CS, Bredt DS, Snyder SH. Cloned and expressed macrophage nitric oxide synthase contrasts with the brain enzyme. Proc Natl Acad Sci USA1992; 89: 6711-5.

133. Arias-Negrete S, Keller K, Chadee K. Proinflammatory cytokines regulate cyclooxygenase-2 mRNA expression in human macrophages. Biochem Biophys Res Commun 1995; 208: 582-9.

134. Lindholm C, Quiding-Jarbrink M, Lonroth H, Hamlet A, Svennerholm AM. Local cytokine response in Helicobacter pylori-infected subjects. Infect Immun 1998; 66: 5964-71.

135. Bamford KB, Fan X, Crowe SE, Leary JF, Gourley WK, Luthra GK, et al. Lymphocytes in the human gastric mucosa during Helicobacter pylori have a T helper cell 1 phenotype. Gastroenterology 1998; 114: 482-92.

136. D'Elios MM, Manghetti M, Almerigogna F, Amedei A, Costa F, Burroni D, et al. Different cytokine profile and antigen-specificity repertoire in Helicobacter pylori-specific $\mathrm{T}$ cell clones from the antrum of chronic gastritis patients with or without peptic ulcer. Eur J Immunol 1997; 27: 1751-5.

137. Karttunen R, Karttunen T, Ekre HP, MacDonald TT. Interferon gamma and interleukin 4 secreting cells in the gastric antrum in Helicobacter pylori positive and negative gastritis. Gut 1995; 36: 341-5.

138. Engstrand L, Scheynius A, Pahlson C, Grimelius L, Schwan A, Gustavsson S. Association of Campylobacter pylori with induced expression of class II transplantation antigens on gastric epithelial cells. Infect Immun 1989; 57: 827-32. 